\title{
Stephen Dale \\ Noble Illusions: Young Canada Goes to War
}

\author{
Black Point, NS: Fernwood, 2014. 112 pp.
}

\section{Jon Weier}

Western University

Over the last fifteen years an ideological conflict has been brewing among Canadian historians of war and culture and, more broadly, among those in Canadian politics and journalism for whom Canada's identity as a "warrior nation" — or as its opposite - is of utmost importance. Stephen Dale's Noble Illusions: Young Canada Goes to War joins a growing recent literature along with books such as Ian McKay and Jamie Swift's Warrior Nation and the recent collection, Worth Fighting For, edited by Lara Campbell, Michael Dawson, and Catherine Gidney, that have critically engaged with Canada's relationship to war and conflict. This growing literature questions, both directly and indirectly, the militarization of Canadian society that has been promoted in conjunction with Canada's participation in an unending "war on terror," and the efforts of successive Canadian governments to justify this participation by linking it to Canadian histories of war.

These three books, and others like them, represent an important corrective to a powerful trend in popular writing and public interventions justifying Canadian militarism by historians such as David Bercuson (The Fighting Canadians) and Jack Granatstein (Who Killed the Canadian Military?) and by public figures such as retired general Rick Hillier and broadcaster Don Cherry. Dale and others seek to remind us that the idea of Canada as a warrior nation is a construct that has found its way into both "Hockey Night in Canada" broadcasts and government policy through a very intentional and explicit process that seeks to minimize and dismiss Canadian histories of peacemaking, pacifism, and war resistance.

A connection to popular culture highlights the real strength and importance of Noble Illusions in the debate. Dale, an established Ottawa writer who has written on children and youth and popular culture, implicitly connects the idea of the warrior nation today and Canadian attitudes towards war a century ago as Canada entered the First World War. Dale does this by examining Young Canada, a boys' magazine 
published in the late nineteenth and early twentieth century that romanticized the British Empire and its civilizing mission, as well as Canada's place as its foremost dominion. Dale asks, given all that happened in the dark twentieth century, whether young Canadians today would be as quick to rally to the colours and fight in a new war. Though he does not necessarily answer this question directly, he does suggest that the promotion of Canada as a warrior nation has this as one goal.

Chapter 1, "The Past as Part of the Present" makes the connection between attitudes that existed in Canada early in the twentieth century and the militarism that has again come to the fore in our own time. Dale also makes explicit the immediate social and political purpose this book is meant to serve. Not only is it a historical examination of this specific children's literature, it is also a warning that, despite our feelings of superiority when we look at our past, we must be vigilant because "now, a century later ... governments have an opportune moment to prune our collective memory. Indeed several are attempting to replace the bleaker view that earlier generations brought home with a more inspirational narrative" (13).

In chapter 2, "A World of Duty, Discovery and Death," Dale examines the 1913 edition of Young Canada. He does this to set a baseline for the types of narratives that were prevalent in this kind of boys' magazine. These narratives presented a view of the world "where oddly idealistic and sensitive young men were schooled in the brutal ways of war, where a haunting sense of innocence commingled with an acceptance of our planet as a savage place that could only be tamed by tempered steel and large quantities of gunpowder" (25). This was a world in which young men could be convinced to go to war for the most tenuous of reasons and a world that our current generation of hawks have sought to recreate. This chapter also features a strong discussion of the agency and reaction of the children who owned these magazines through a study of inscriptions, marginalia, and mementoes, as well as a broader discussion of the children's literature of the First World War era.

The third and fourth chapters, "In the Thick of Things" and "Will Something New Arise from the Ashes?", continue to chart the evolution of narratives in Young Canada in the 1916 and the 1918 editions. These attitudes seem to mirror trends that have already been identified in the broader First World War historiography: a sense of determination in the 1916 edition as well as a fascination with new military technologies, and a sense of fatigue and reluctant support for the continued prosecution of the war in the 1918 edition. Chapter 4 ends with a reminder of Dale's purpose in writing Noble Illusions, that this is a book that seeks to remind us of the "horrors and sheer, immoral waste of life" associated with the First World War and to ensure "that future generations will not have to go through that process" of "bitter experience" (106).

Noble Illusions could have benefited from a more in-depth discussion of the relationship between war, militarism, and popular culture in the twentieth century, but that would have necessitated a longer book and a more in-depth historical focus. And as Dale himself notes, this is not the intent of this book; it is intended to contribute to an ongoing and important public discussion that is especially relevant as Canada's war on terror enters a new phase in Iraq and Syria. I would also have liked to have 
seen more recognition that children and youth have agency when making decisions around military service and that factors other than propaganda and popular culture contribute to military recruitment and support for war.

But these are small concerns in what is an important and timely book. At four chapters and just over 100 pages, Noble Illusions is a useful and accessible book for those interested in both an examination of militaristic popular culture directed towards youth during the First World War, as well as how modern popular culture seeks to recreate the conditions that would allow young Canadians to see themselves as warriors in a new war for civilization. 